\title{
Contrasting the Request Act Used by EFL ESL Native- Arabic Speakers in Arabic and English Situations
}

\author{
Shadi Majed Alshraah ${ }^{1, *}$, Amer Ahmed Daradkeh ${ }^{2}$ \\ ${ }^{1}$ Department of English, Instructor at Prince Sattam bin Abdulaziz University, Saudi Arabia \\ ${ }^{2}$ Ministry of education, Jordan \\ *Corresponding Author
}

Received: 20 May 2021; Received in revised form: 08 Jun 2021; Accepted: 18 Jun 2021; Available online: 27 Jun 2021 C2021 The Author(s). Published by Infogain Publication. This is an open access article under the CC BY license (https://creativecommons.org/licenses/by/4.0/).

\begin{abstract}
The current study sought to identify the request strategies used by EFL native-Arabic speakers in Arabic natural situations and also to identify the request strategies used by EFL native-Arabic speakers in English natural situations. And in more depth vein, it tried to shed light on role the environment of learning English, socio-cultural differences, human mentality and requesting transferring in requesting. 30 EFL Arabic lecturers and 30 ESL Arabic lecturers at Prince Sattam bin Abdulaziz University completed Discourse Completion Test (DST) consists of 12 written context situations (appendices I and II). The finding revealed that both EFL and ESL use conventional indirect request strategies more than direct request strategies which in turns are used more than non-conventional requests strategies either in Arabic or in English situations. Moreover, it appears to assume that human mentality and socio-cultural differences affect more the strategies of requesting.
\end{abstract}

Keywords - Pragmatic competence, communication strategies, requests, pragmatic transfer.

\section{INTRODUCTION}

The interest in the pragmatic aspect of linguistic investigation especially in the field of foreign language learning and teaching was definitely accumulating during the last two decades [26]. This leads to the theoretically or practically to investigate various pragmatic issues such as the notion of communicative competence, the distinctness of communicative competence and linguistic competence and also the ability of non-native speakers to communicate appropriately in certain situations [14]; [9] and [18]. As a consequence, communicative competence is a vital condition to guarantee successful interaction between speakers and to avoid miscommunication.

In light of the significance of Communicative Competence (CC), it has been receiving plenty of efforts to define by theoreticians and researchers [11], [12], [20]). As one of the seminal models of determing Communicative Competence, [6] classified communicative language model into two branches; pragmatic and organizational model. In which, the pragmatic competence refers to the sociolinguistic and illocutionary adequacy while the organizational competence deals with speaker's knowledge of syntax, morphology and grammar. As a new model, [25] views Communicative Competence (CC) as the speaker's capability to employ all of speech act strategies. She suggested five intrinsic parts of competence listing as the following: interactional, linguistic, formulaic, strategic, discourse, pragmatic and sociocultural competence. For the sake of study, the interactional competence comprises conversational and action competence which focus on the speaker's knowledge of cultural-norms and conventions in producing and perceiving speech act and also how to establish the ability to opening and closing conversation.

In fact, the literature about the interactional competence states that it is not universally identical, but the fact is that the recognition of speech act varies from language to another. As a result, it is crucial for speakers to grasp the cultural norms and conventions of the target 
language in order in purpose of achieving successful communications. More specifically, acquiring Request Acts as a part of speech act are necessary tools for native speakers and non-native speakers of language to do well in their everyday communications [11], [27]. The current study attempts to contrast the request strategies that are used by EFL/ESL native speakers of Arabic in Arabic situations and in English situations in order to determine the aspects of transferring of request strategies from Arabic into English. Thus, the study provides the literature with the request strategies used in Arabic situations, the request strategies used in the English situation and the effect of the native request strategy in the target ones. It is worth note that the study differs between the Arabic speakers who acquire English language in an English country and the native Arabic speakers who learn English language in an Arabic country. So, the results are going to be more comprehensive because they state about the transferring of request strategies into English under different language- learning environments.

\subsection{THEORETICAL BACKGROUND}

Pragmatics, as a branch of linguistics, has been defined from different perspectives. One of the prominent elucidations of pragmatics is how to recognize language within the frame of sociocultural norms and communication actions. These communicative actions include a variety of viewpoints in performing speech acts such as (request, thanking, complaint). Pragmatics plays a vital role in using language as the core element in communication. Hence, speakers should develop their pragmatic awareness to produce and perceive the target language conveniently depending on the situation [13] Being successful in interaction with others in real situations requires passing the linguistic competence to acquire pragmatic competence which has been attaining the specialists' interest to identify. For instance, [19] defined pragmatic competence as the capability to exploit linguistic knowledge in communicative actions based on contextual factors. In the same vein, [16] classified pragmatic competence into two fields. The former is the sociopragmatic adequacy which focuses on how to employ social factors (power, imposition, and social distance) in communications. And the latter is the Pragmalinguistic adequacy deals with the capability to use the proper linguistic utterances in a particular context. In addition, [7] described the pragmatic competence as the realization of the availability of linguistic resources in any language to understand the illocutions, awareness of the critical aspects of speech acts and the familiarity of the appropriateness of the contextual use in the target language.

The integration between linguistic utterance and social norms relies on the impact of social factors in the process of choosing the appropriate linguistic actions [25]. To sum up, pragmatic competence includes two angles; pragmatic knowledge and also using this knowledge appropriately. The first angle interests in the linguistic choice in employing speech acts (pragmalinguistics). And the second angle refers to the ability to use the range of linguistic choice in a specific setting to achieve a particular goal (sociopragmatics). The previous presentation of pragmatic competence as a whole supports its necessity to avoid misunderstanding, misuse, and misstep during communications in the target language. Moreover, this presentation indicates that EFL learners' need is not only the familiarity of accuracy and proficiency in the target language, but they also need to improve their pragmatic competence.

As well as, Intercultural communication competence greatly recommends that ESLIEFL learners should be familiar to cultural and humanistic perspective and not to be restricted to language and communicative acquisition without ignoring and belittling the speaker's 1L [5] Furthermore, learners should mediate midst the language culture and culture of the target language as well as their own culture and language.

In the field of language acquisition, linguists and applied linguists argued entitled the contrastive analysis especially during 1940s the language "transfer" (Fries, 1945). It was stands one main idea is that the speakers' native language makes either positive or negative effects in the process of acquiring the foreign or second language. More specifically, the similarities between the two languages leads to positive transfer which facilitates the process of acquisition whereas the differences between the two languages makes negative transfer called interference causing improper employ of language features. As well as the same case has been discussing in the field of pragmatics under the title "pragmatic transfer" (PT) which is described based on [15] as "in the influence exerted by learners' pragmatic knowledge of language and culture other than L1 in their comprehension, production and learning of L2 pragmatic information. PT was classified into two branches; pragmalinguistic transfer and sociopragmatic transfer [23]. The pragmalinguistic transfer, as the main goal seeks this investigation to scrutinize on in terms of request acts, focuses on the request strategies such as external and internal modifications. And on the other side the sociopragmatic transfer is an examination of the perception and performance of the speech act. In which, the perception interests in the contextual variables such as difficulty imposed and right, and the performance look at the social distance and status. 
This term is always connected with pragmatic failure [24] which deals with speaker's failure to match the pragmatic norms of the target language based on his ther own norms. Having insufficient of communicative competence may lead to pragmalinguistic and sociopragmatic failure. Sociopragmatic failure may happen when the speaker shows no focus on social status and employs incorrect expressions when addressing someone in a higher rank. Whereas, pragmalinguistic failure may occur when the speaker uses speech act inappropriately when transferring from first to second language [24].

\subsection{LITERATURE REVIEW}

[17] conducted a cross-culturally investigation aims to determine the request strategies that are used by Uruguayan Spanish (US) and British English (BE). The findings revealed that the subjects of the languages prefer to use conventionally indirect strategies more than other request strategies. The study also showed that Uruguayan Spanish (US) used direct strategies more than British English (BE) who tend to use non-conventionally indirect strategies more than the other group. In addition, higher levels of directness indicated in US to appropriateness on opposite of BE. And negative politeness was appeared weighty in US but it is so in BE.

[1] aimed at studying the production and perception of requests. The study tries in production to investigate how Iraqis realize requests in socially and culturally appropriate forms. And it attempts in perception to determine the subjects' awareness of the rules govern selecting requests. The data were collected from 10 Iraqi who filled the Discourse Completion Test (DCT) and a Multiple Choice Questionnaire (MCQ). And the analysis of this data revealed two main results. Firstly, the participants of the study showed preference to use conventionally indirectness especially in question forms and modals. And the latter is that the sample of this study was unaware of the social and situational rules affect to make the appropriate request.

[2] compared the linguistic mitigating devices in making requests used by EFL Jordanian learners with those that are used by native speakers of American English. This comparison provides a look at the samples' linguistic mitigation knowledge as well as the factors that affect their behaviors in request. The study divided the participants in two groups. The first group consists of (45) Jordanian undergraduate students (19 male and 26 female) of English in four different Jordanian public universities. And the other group consists of (45) American University students who study different majors in two American Universities: Kent State University, Kent and The
University of Akron, Akron. This study discovered that there are differences in requesting in terms of type, frequency and linguistic perception and the structure of request acts. Moreover, Language ability, L1 pragmatic knowledge and L1 cultural norms transfer play a crucial effect on making non-native speakers' behaviors in requests.

In 2012, [22] studied the(in)directness and politeness in purpose of defining the request strategies used in Saudi Arabic and American English as well as the effect of social factors, distance and rate of imposition in choosing the request strategies. A discourse completion test that comprises 12 situations was completed by 30 Saudi and American undergraduate students whom were divided in two groups. The findings of this study indicated that the American participants emerged mostly the conventional indirectness strategies while Saudi participants used conventional indirectness in addressing inferiors to superiors. The social variables of power and distance played a crucial effect on varying the request strategies used by the Saudi sample. Moreover, the level of directness was affected cross-culturally. Saudi students mostly used the direct request strategy in addressing superiors to their inferiors and also in communicating requests with friends. Thus, the direct strategy was interpreted as closeness and connectedness and affiliation instead of impoliteness. On the other hand, American students used the direct strategy in communicating with their close friends where there were low rate of imposition and minus distance (- distance).

Through analyzing data from English and Moroccan Arabic materials, [3] scrutinized formats in which politeness formula emerged in the speech acts of requests, offers and thanks. The results refer that politeness and reducing face-threat are highly required in both languages. Modals and questions are favoured in English it is a marker of politeness in Moroccan Arabic.

[4] conducted a study to investigate the use of polite request strategies in terms of two distinct interactions; in male- male interaction and male - female interaction by Native speakers of Yemeni Arabic. To achieve this goal, 168 Yemeni male and 168 Yemeni female university students wrote in Yemeni Arabic their responses about six situations in a "Discourse Completion Test" (DCT) prepared by [8] Then the investigators got the results by analyzing the data based on [10]'s models. The findings generally showed that Male speakers of Yemeni Arabic in male - male interaction trend to use higher levels of directness especially mood derivable strategy and want statements strategy while they trend in male - female interaction to use higher levels of indirectness. In which, they used mostly query preparatory and suggestory 
formulae as conventional indirectness and strong hints strategy as non-conventionally indirectness.

The Arabic practical studies in the literature of request strategies research generally scrutinize these many issues: 1. comparing between the request strategies used in a certain Arabic dialect and the request strategies used in a certain English dialect. 2. The extent of Arabic speakers' awareness of using the request strategies. 3. Defining the factors that influence choosing request strategies in different situations. And 4. Identifying the request strategies used by EFL native-Arabic learners.

The current study attempts to feed the fourth issue mentioned above. In which, three ultimate goals are sought to achieved. The former is to identify the exact request strategies used by native-Arabic speakers in Arabic natural situations. The second is to identify the exact request strategies used by native-Arabic speakers who acquire or learn English language in different settings. The new point in this study sheds light on the effect of learning English environment (Arabic educational institutions and in nativeEnglish institutions) on using the request strategies in English situations. And the third goal is to shed light on the pragmatic development of using request strategies in English as a foreign language. This goal also provides new insight to the literature by following the pragmatic transfer of using request strategies in different linguistic contexts.

\subsection{Research questions}

The current study attempts to answer the following questions:

1. What are the exact request strategies used by EFL native-Arabic speakers in Arabic natural situations?

2. What are the exact request strategies used by EFL native-Arabic speakers in English natural situations?

\section{METHOD}

In this section of the study, participants, instruments, procedures of data collection and data analysis are presented as the following.

\subsection{Sample/ Participants}

The data of this study were collected from a random sample contains (60) male and female EFL Arabic individuals from different Arabic countries - as illustrated in the diagram below - at Prince Sattam bin Abdulaziz University in various departments. The participants were divided into two groups: The former contains (30) male and female EFL Arabic lecturers at Prince Sattam bin Abdulaziz University. The native language of all members of this group is Arabic. And they are aged from 30 till 50 years old. They all specialized in one of native English countries such as The United States of America, The United Kingdom and Australia. Thus, they lived in a native-English environment especially in an academic one for at least four years. Therefore, they acquired English language in natural settings. The latter group consists of (30) EFL male and female Arabic students at Prince Sattam bin Abdulaziz University. Their native language is Arabic and their age is from 18 to 22 years old. As an overall, the participants in the two groups are almost homogeneous; they share the same Islamic norms and cultural. But the mainly difference between the two groups is that the first group of subjects used English language in native-English environments while they were studying in one of the native-English country and the members of the other group did not travel to any native-English country at all and they learn English language at Arabic educational institutions.

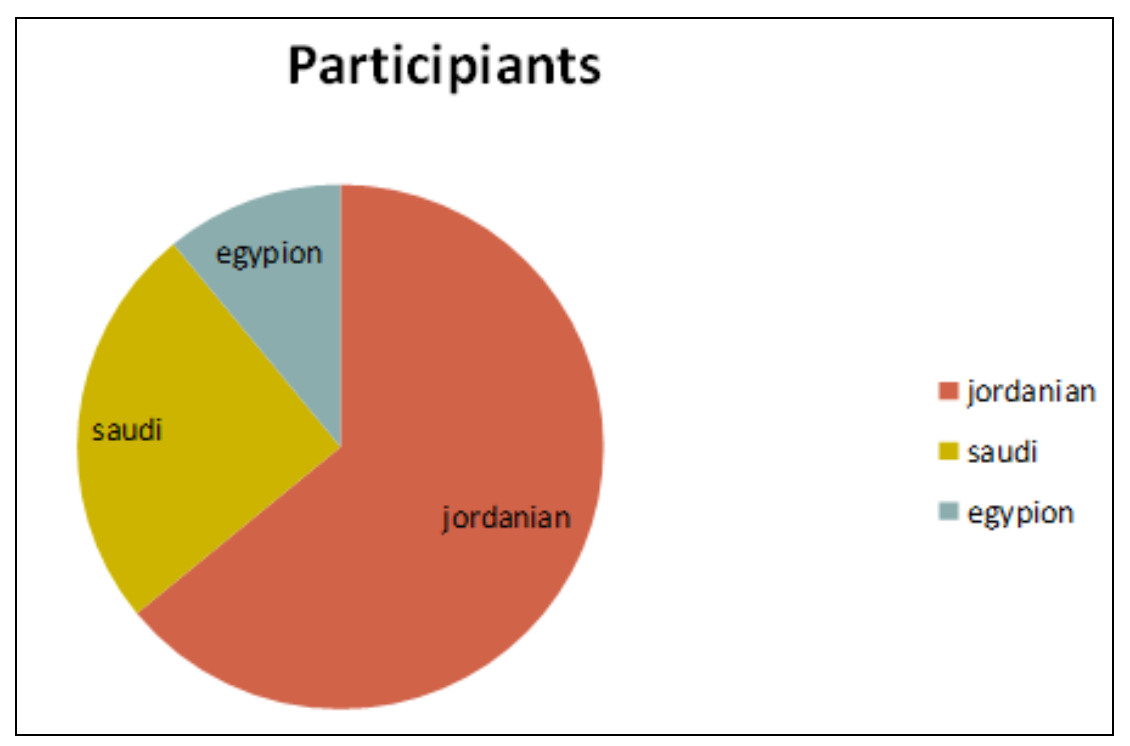

Diagram 1: Distribution of the Sample's Individuals 


\subsection{Instrument(s)}

The current study used to achieve its aims a Discourse Completion Test (DST). This instrument that was originally designed by [8] and developed by [17] is a questionnaire consists of 12 written context situations (appendices I and II). Each situation is context-enriched in which the requestive goal, the description of the setting, social dominance, social distance, the role-relationship, the frequency of the interaction and the length of acquaintance were clearly explained. To be fit with questions of this study, the questionnaire was used in two versions. The former is an Arabic that was translated from English in order to determine the request strategies that native Arabic speakers use in Arabic situations. And the latter is an English one which was designed to emerge the request strategies used by Arabic speakers who acquired English language naturally the native English countries.

\subsection{Data collection procedures}

The procedures of data collection passed three steps as follow. The investigators firstly selected the individuals of the sample who are appropriate to the objectives of this study and then classified into two groups; the former contains native Arabic speakers who acquire English language in a native-English country, and the other contains native Arabic speakers who learn English language in a native-Arabic country. The individuals were administered the Arabic version of the questionnaire to react a request for each situation in written. Secondly, the same individuals answered after a week by a request the English version of the corresponding questionnaire in written. And finally, data were gathered to be ready for analyzing and getting results.

\subsection{Data analysis}

To answer the research questions, the present study adopts [10] classification of request strategies which was amended by [21]. This classification categorized request strategies in three segments containing twelve request strategies that are illustrated in-depth as the following:

A. Direct (HA): this type is realized by explicit linguistic utterances, which includes high level of directness (Mood Derivable) to lowest level of directness (Mild Hint). It contains:

1. Imperative: the illocutionary force of the utterance is determined grammatical mood (e.g. Cancel this order)

2. Performatives: the illocutionary force of the utterance if explicitly performed (I ask you to change this chair)

3. Implicit performative: speaker opts to employ hedging expressions to modify illocutionary force in utterance. (I'd like to ask you to bring cup of tea)
4. Obligation statements: the speaker uses obligation expressions to perform an act (you have to turn down the volume)

5. Want statements: the speaker shows histher desire from the addressee to perform the act (I want you to lend me your notebook)

B. Conventionally indirect: Conventional indirect: this type is recognized by structural, linguistic, and contextual device. This classification involves query preparatory and Suggestory format.

6. Preparatory question: speaker uses preparatory condition such as willingness and ability (could you mind carrying this bag)

7. Suggestion: speaker use suggestion form in the utterance to perform an act (How about changing this order)
8. Permission
9. Mitigated preparatory
10. Mitigated wants

C. Non-conventionally indirect level:

11. Strong hints: the locution includes reference to factor required to perform the intended illocutionary act. (It's hot in this room)

12. Mild hints: the locution does not include reference to perform the intended illocutionary act which is derived from context.

The researchers collected the samples' responses towards the situations. Then they analyzed each response carefully in purpose of classifying it into the appropriate segment and also into the certain request strategy as defined above. Finally, the whole classification of participants' responses was analyzed by the SPSS formula to get the results.

III.

RESULTS

\section{First Question:}

SPSS analysis was performed to answer the first question of this study "What are the exact request strategies used by EFL native-Arabic speakers in Arabic natural situations? The results in table 1 represents a comprehensive figure about the frequencies of all request strategies that are used by Arabic learners -who learnt English language as a foreign language in only Arabic countries- in particular 12 situations in both Arabic and English. 
Table 1. The Frequency of the Requests Strategies made by Male/Female EFL Learners across Arabic and English Situations

Situations $\quad$ Request Strategies

Situations Direct Expressions Conventional Indirect Non-Conventional Indirect

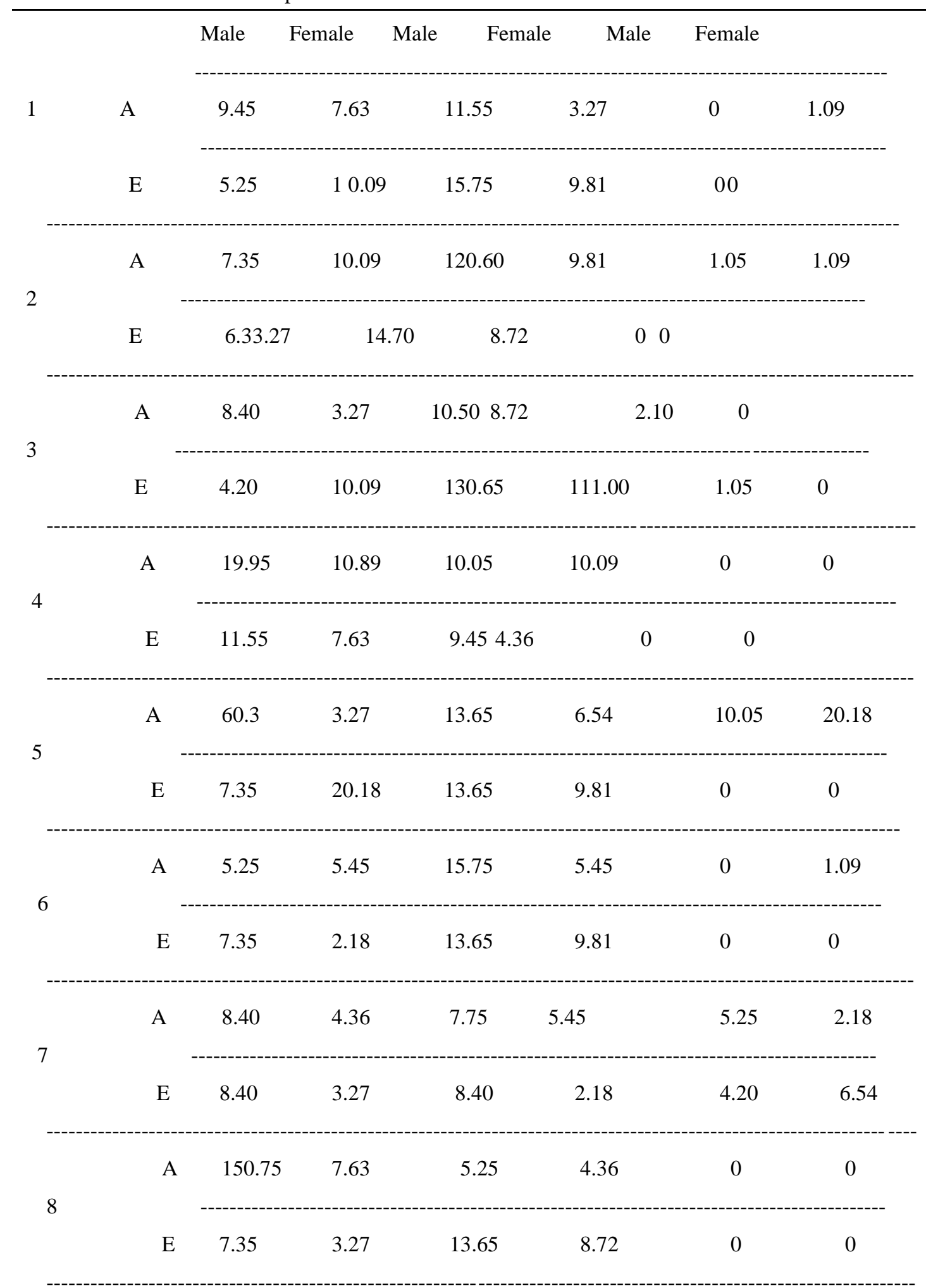



4.36
$9.45 \quad 6.54$
1.05
1.09

9

$\begin{array}{lllllll}\text { E } & 6.30 & 1.09 & 14.70 & 9.81 & 1.05 & 1.09\end{array}$

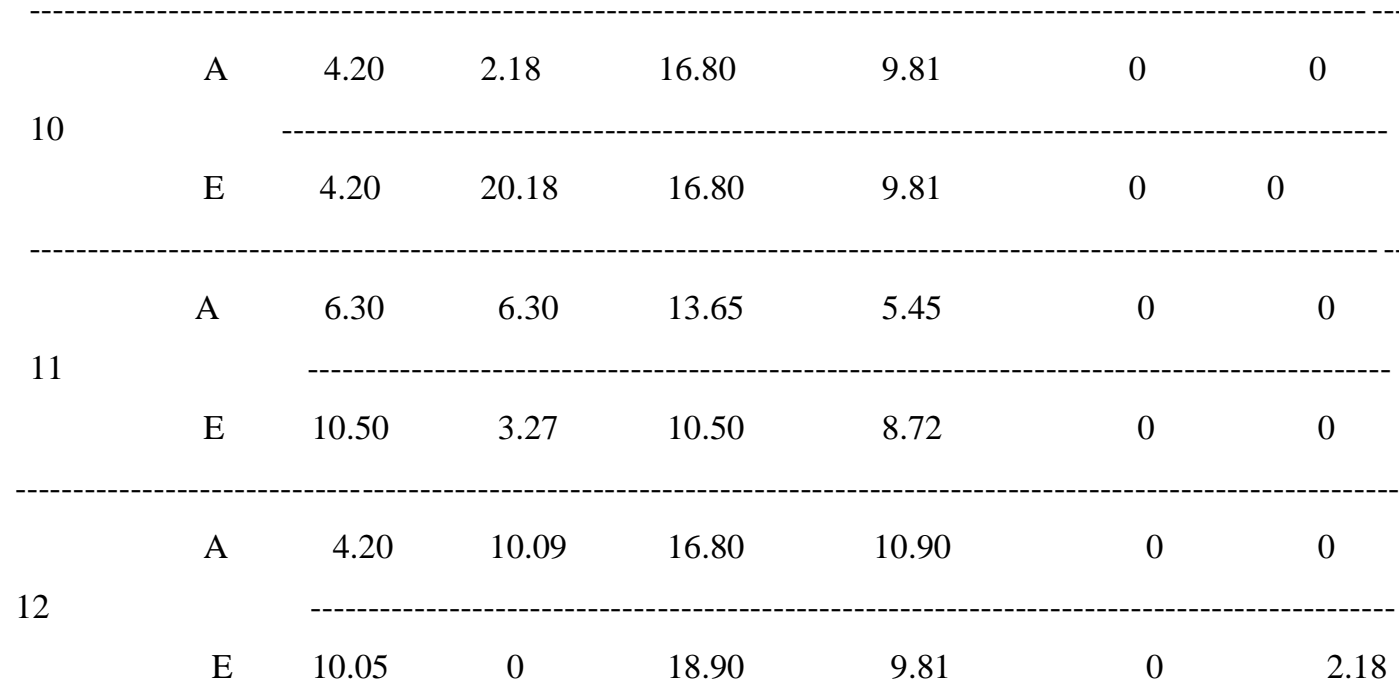

As shown above, the results give each request strategy (Direct, Conventional Indirect and Non-Conventional Indirect strategies) alone showing their frequencies in responding male and female Arabic EFL learners in 12 situations administered in Arabic and English. To be more specific, the analysis in table 2 below provides the sum of frequencies for each request strategy that are used in only Arabic 12 situations by male and female Arabic learners who learnt English language in only Arabic Educational institutions.

Table 2. Frequencies of Request Strategies in Arabic Situations by EFL Arabic Learners

\begin{tabular}{|c|c|c|c|c|c|}
\hline & Frequency & Percent & & Valid Percent & Cumulative Percent \\
\hline Direct & 154 & 19.7 & 41.3 & 41.3 & \\
\hline Conv. & 201 & 25.7 & 53.9 & 95.2 & \\
\hline Non-conv. & 18 & 2.3 & 4.8 & 100.0 & \\
\hline Total373 & 47.8 & & 100.0 & & \\
\hline Missing & 408 & 52.2 & & & \\
\hline Total781 & 100.0 & & & & \\
\hline
\end{tabular}

And here below in table 3 shows the sum of frequencies for each request strategy that are used in only English 12 situations by male and female Arabic learners who learnt English language in only Arabic Educational institutions.

Table 3. Frequencies of Request Strategies in English Situations by EFL Arabic Learners

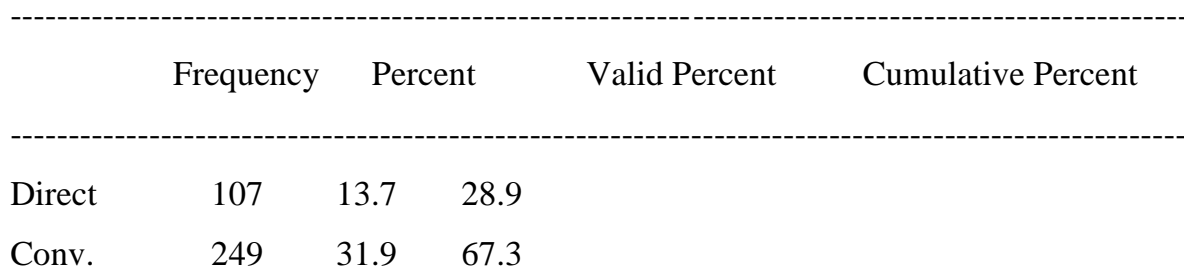




$\begin{array}{llll}\text { Non-conv. } & 14 & 1.8 & 3.8 \\ \text { Total370 } & 47.4 & 100.0 & \\ \text { Missing } & \text { System } & 411 & 52.6 \\ \text { Total781 } & 100.0 & & \end{array}$

The comparison between the two tables above $(2,3)$ indicates that conventional Indirect request strategies are used more than direct and non-conventional request strategies either in Arabic or in English. The frequencies of using conventional indirect strategies by native Arabic learners of English in Arabic countries used were 201 with $25.7 \%$ in the Arabic situations, and it was in the English situations 249 with $31.9 \%$. It is noted that those EFL Arabic learners used conventional strategies in English situations more than that in Arabic situations which is fit with the previous studies that confirmed that English people tend to use more the conventional indirect request strategies. In addition, EFL Arabic learners used direct request strategies in Arabic and English situations more than they used non-conventional indirect request strategies which based on SPSS analysis got few frequencies (18 in Arabic situations and 14 in English situations).

\section{Second Question:}

In term of answering the second research question "What are the exact request strategies used by EFL nativeArabic speakers in English natural situations", table 4 provides the details of using ESL Arabic learners -who acquired English in native English country- the three main strategies. The table is as the following:

Table 4. The Frequency of the Requests Strategies made by Male/Female ESL Learners across Arabic and English Situations

Situations $\quad$ Request Strategies

Situations Direct Expressions Conventional Indirect Non-Conventional Indirect

\begin{tabular}{|c|c|c|c|c|c|c|c|}
\hline \multirow{3}{*}{1} & \multirow{3}{*}{$\begin{array}{l}\mathrm{A} \\
\mathrm{E}\end{array}$} & \multirow{2}{*}{$\begin{array}{c}\text { Male } \\
4.66\end{array}$} & \multirow{2}{*}{\begin{tabular}{r}
\multicolumn{1}{l}{ Female } \\
2.22
\end{tabular}} & \multirow{2}{*}{ Female } & \multirow{2}{*}{$\begin{array}{r}\text { Male } \\
7.77\end{array}$} & \multicolumn{2}{|l|}{ Female } \\
\hline & & & & & & $\begin{array}{ll}0 & 1.11\end{array}$ & \\
\hline & & 1.16 & 0 & 5.83 & 8.88 & 1.16 & 1.11 \\
\hline \multirow{2}{*}{2} & A & 2.33 & 1.11 & 4.66 & 8.88 & 0 & 0 \\
\hline & $\mathrm{E}$ & 2.33 & 2.22 & 4.66 & 5.55 & 0 & 1.11 \\
\hline & $\mathrm{A}$ & 3.50 & 1.11 & 2.33 & 8.88 & 1.16 & 0 \\
\hline & $\mathrm{E}$ & 2.33 & 4.44 & 4.66 & 5.55 & 0 & 0 \\
\hline \multirow{3}{*}{4} & A & 5.83 & 6.66 & 1.16 & 3.33 & 0 & 0 \\
\hline & $\mathrm{E}$ & 4.66 & 7.77 & 2.33 & 2.22 & 0 & 0 \\
\hline & $\mathbf{L}$ & 4.00 & 1.11 & 2.35 & 2.22 & 0 & 0 \\
\hline
\end{tabular}




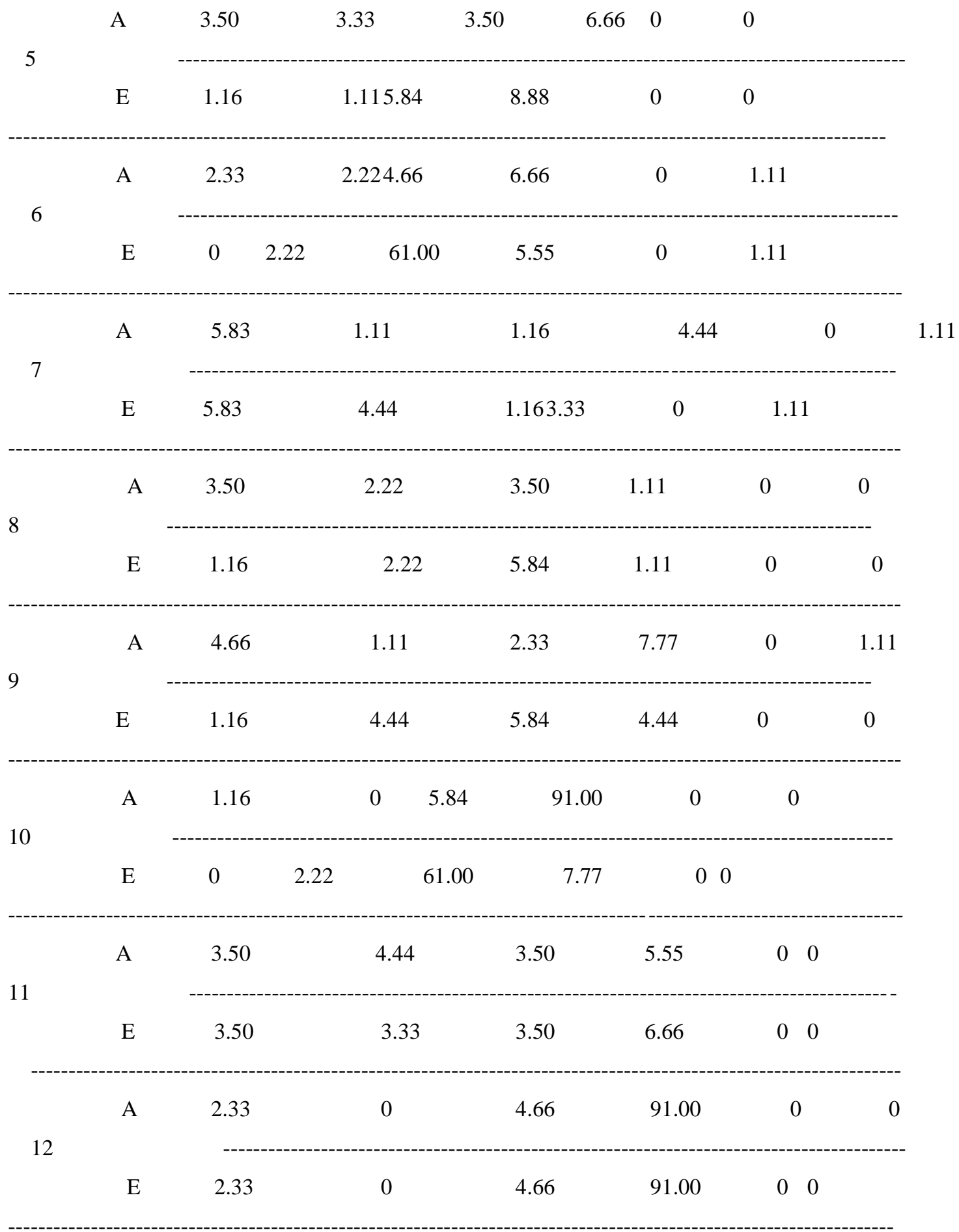

(Note: A refers to Arabic Situations, B refers to English Situations)

To preview the results of the second question, the research provides the following tables; Table 5 shows the sum of frequencies and percentages of using the request strategies in Arabic situations only by Arabic leaners of English who learn it in native English institutions in one of native - English country. 
Table 5. Frequencies of Request Strategies in Arabic Situations by ESL Arabic Learners

Frequency Percent Valid Percent Cumulative Percent

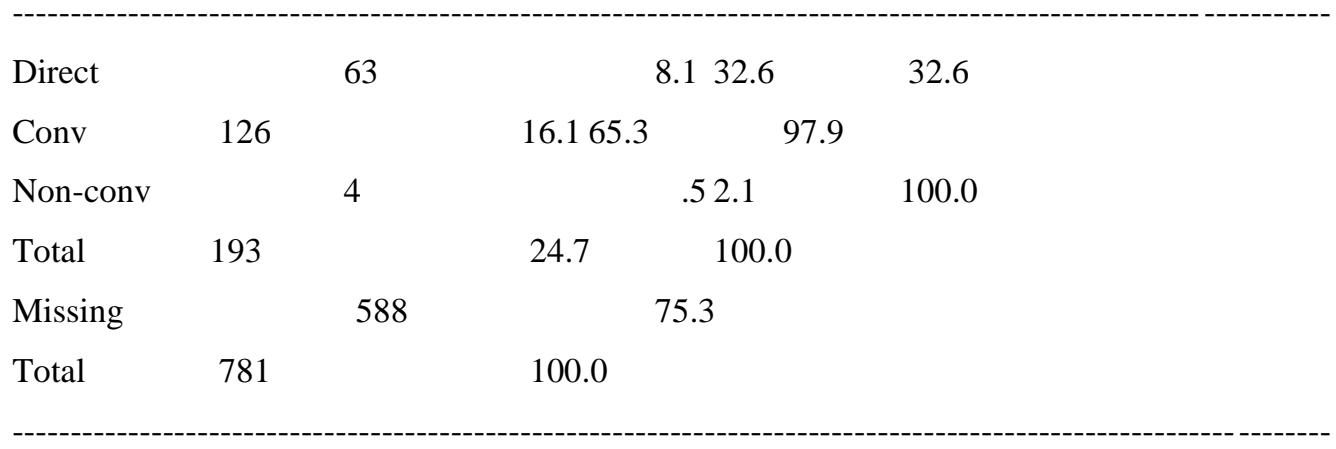

(Note: $0=$ Direct, $1=$ Conventional, $2=$ Non-Conventional)

And the other table (table 6 below) represents the sum of frequencies and percentages of using the request strategies in only English situations by Arabic leaners of English who learn it in native English institutions in one of native - English country.

Table 6. Frequencies of Request Strategies in English Situations by ESL Arabic Learners

Frequency Percent Valid Percent Cumulative Percent

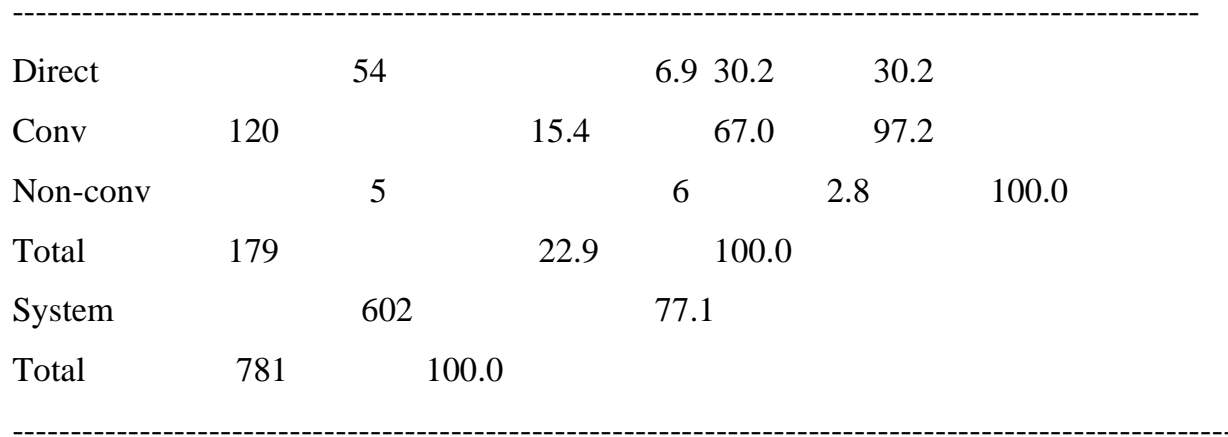

Comparing the two tables above $(5,6)$ indicates that conventional indirect request strategies in Arabic and English situations are used more by ESL Arabic learners than the other strategies; direct and non-conventional request strategies. The frequencies of using conventional indirect strategies by ESL native-Arabic learners of English in native-English countries used were 126 with $65.3 \%$ in the Arabic situations, and it was in the English situations 120 with $67 \%$. It is worth note that the participants of ESL Arabic learners used conventional indirect strategies in Arabic situations more -but with no bid difference- than that in English situations which refers that people in Arabic and English cultures prefer to use more the conventional request strategies. Moreover, the two tables shows that ESL Arabic learners used "Direct request strategies" in Arabic (32.6\%) and English situations (30.2) more than they used non-conventional indirect request strategies in Arabic situations (2.1) and in English situations (2.8) which indicate very few frequencies.

\section{DISCUSSION}

The first result this study reports is that those Arabic learners who learnt English language in one of Arabic schools of English without travelling to live in one of native-English country or take any course there tend to use more conventional Indirect request strategies more than other strategies in both languages and situations; Arabic and English. This result comes in line with previous studies such as [17] which found that British English and (BE) Uruguayan Spanish (US) prefer to use conventionally indirect strategies more as well as [1] revealed that the participants (10 Iraqis) use conventionally indirectness 
especially in question forms and modals. Thus, the studies support that conventionally indirectness are more used in Arabic and English situations. The conventional indirect strategies involving preparatory question, suggestion, permission, mitigated preparatory and mitigated wants tend to avoid the directness in requesting which may appear sharp and impolite especially in addressing inferiors to superiors where is no closeness. Moreover, confirming the same result (using conventionally indirectness more) in different studies gives a reference need more scrutiny in which requesting and its strategies may exceed the exact border of language to the socialcultural differences and also the modular of human mind as a whole. This reference is supported more in this study by finding two extra results: the former is that the frequencies of using conventional indirect strategies in Arabic situations (201) and the frequencies of conventional indirect strategies in English situations (249) is not a big difference. And the latter is that the direct request strategies in both Arabic and English were used more by the same participants than non-conventional requesting.

Going to search using request strategies by Arabic learners who lived many years to study in one of the native-English countries (ESL), they also use conventional indirect request strategies in both Arabic and English situations more than other strategies. In the same vein, Tawalbeh and Al-Oqaily (2012) compared between American English and Saudi Arabic participants in using requesting and found that they used more conventionally requesting. The frequencies of using conventional request strategies in Arabic situations (126) and in English situations (120) are very close which may refer to the effective role of the human mentality as a whole in requesting. And the few differences may relate to the socio-cultural values which may classify inferiors to superiors and the addressing between them in different look. In addition, ESL Arabic learners used direct requesting in Arabic and in English situations more than non-conventional indirect requesting as the EFL did.

\section{CONCLUSIONS}

The following study was designed to investigate two main issues: to identify the request strategies used by EFL native-Arabic speakers in Arabic natural situations and to identify the request strategies used by EFL native-Arabic speakers in English natural situations. As well as, the goal is to infer some indications related to role of many supposed factors in the issue such as the environment of learning and cultural differences, human mentality and requesting transferring. The main result the study found is that both EFL and ESL use conventional indirect request strategies more than direct request strategies which are used more than non-conventional requests strategies either in Arabic or in English situations. The interesting point here is that many previous studies confirm the same result in which the participants use conventionally requesting more and the sub-difference in using each class of request strategies is not large. This motivates to infer that human mentality and socio-cultural differences rather than request transferring has a crucial influence in using requesting. Confirming in many studies in the literature the existence of similarities more than differences in using request strategies opens to suppose that the effect of human mentality more effective in requesting than socio-cultural differences which in turns has greater role than request transferring. This study motivates researchers to conduct several studies to investigate the effect of the environment of learning and cultural differences, human mentality and requesting transferring in requesting.

\section{REFERENCES}

[1] Abdul Sattar, H., Lah, S., \& Suleiman, R. (2009). Iraqi postgraduates' production and perception of requests: A pilot study. The International Journal of Language Society and Culture, 29, 56-70.

[2] Al-Ali, M., \& Alawneh, R. (2010). Linguistic mitigating devices in American and Jordanian students' requests. Intercultural Pragmatics, 7(2), 311-339. http://dx.doi.org/10.1515/iprg.2010.014

[3] Alaoui, S. M. (2011). Politeness Principle: A Comparative Study of English and Moroccan Arabic Requests, Offers and Thanks. European Journal of Social Sciences, 20(1), 715.

[4] Al-Marrani, Y. M. A., \& Sazalie, A. (2010). Polite request strategies by male speakers of Yemeni Arabic in male-male interaction and male-female interaction. The International Journal of Language Society and Culture, 63.

[5] Alptekin, C. (2002). Towards intercultural communicative competence in ELT. ELT journal, 56(1), 57-64.

[6] Bachman, L. F. (1990). Fundamental considerations in language testing. Oxford university press.

[7] Barron, A. (2003). Acquisition in interlanguage pragmatics: Learning how to do things with words in a study abroad context (Vol. 108). John Benjamins Publishing.

[8] Blum-Kulka, S. (1982). Learning how to say what you mean in second language: a study of speech Act performance of learners of Hebrew as a second language. Applied Linguistics, 3, 29 -59.

[9] Blum-Kulka, S. (1983). Interpreting and performing speech acts in a second language: across cultural study of Hebrew and English socio-linguistics and language acquisition. Rowley, A: Newbury House.

[10] Blum-Kulka, S. et al's (1989). Cross cultural pragmatics: requests and apologies. Norwood, New Jersey. Ablex.

[11] Canale, M., \& Swain, M. (1980). Theoretical bases of communicative approaches to second language teaching and testing. Applied linguistics, 1(1), 1-47. 
[12] Gumperz, J. J. (1982). Discourse strategies (No. 1). Cambridge University Press.

[13] Hymes, Dell. "On communicative competence." sociolinguistics 269293 (1972): 269-293.

[14] Johnson, K. \& Johnson, H. (1999) Encyclopedic Dictionary of Applied Linguistics, Blackwell Publishers

[15] Kasper, G. (1992). Pragmatic transfer. Interlanguage studies bulletin (Utrecht), 8(3), 203-231.

[16] Leech, G. N. (1983). Principles of Pragmatics London: Longman Group Ltd.

[17] Reiter, R. (2000). Linguistic Politeness in Britain and Uruguay: A Contrastive Study of Request and Apology. Amsterdam Philadelphia: Benjamin's J. Publishing Company.

[18] Rintell, E. (1981) Getting Your Speech Act Together: The Pragmatic Ability of Second Language Learners, A working paper on Bilingualism. The TESOL Convention: Washington D. C.

[19] Roever, C. (2005). Language testing and evaluation: Testing ESL pragmatics: Development and validation of a web-based assessment battery. Lang-Peter Lang.

[20] Saville-Troike, M. (1996). 11 The ethnography of communication. Sociolinguistics and language teaching, 351.

\section{Appendix I: Questionnaire--Arabic Version}

[21] Taguchi, N. (2006). Analysis of appropriateness in a speech act of request in L2 English. Pragmatics, 16(4), 513-533.

[22] Tawalbeh, A., \& Al-Oqaily, E. (2012). In-directness and politeness in American English and Saudi Arabic requests: A cross-cultural comparison. Asian Social Science, 8(10), 85.

[23] Tello Rueda, Y. (2006). Developing pragmatic competence in a foreign language. Colombian applied linguistics journal, (8), 169-182.

[24] Thomas, J. (1983). Cross-cultural pragmatic failure. Applied linguistics, 4(2), 91-112.

[25] Usó-Juan, E., \& Martínez-Flor, A. (2010). 14. The teaching of speech acts in second and foreign language instructional contexts. In Pragmatics across languages and cultures (pp. 423-442). De Gruyter Mouton.

[26] Widdowson, H. G. (1987) Teaching Language as Communication. Oxford: Oxford University Press.

[27] Wolfson, N., \& Judd, E. (1983). Sociolinguistics and Language Acquisition. Newbury House Publishers, Inc, Rowley, MA 01969.

$$
\begin{aligned}
& \text { التخصص: }
\end{aligned}
$$

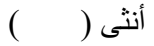

$$
\begin{aligned}
& \text { :الاسم:(اختياري): } \\
& \text { ذكر ( ) ) } \\
& \text { شكر ا على قيامك بالإجابة على هذا الاستبيان و الذي يهدف إلى دراسة موضوع الطلب باللغة العربية العامية المستخدمة في السعودية ـ يحتوي هذا } \\
& \text { الاستبيان على اثني عثر موقف ـ المطلوب منلك هو أن تقوم بالكتابة في الفراغ آما تتوقع أن تقول في ذلك الموقف آمالو أنه حقيقي و و اقعي } \\
& \text { يرجى آتابة آل ما يمكن أن تقول قبل و بعد الطلب الأساسي. هذا الإستبيان هو لإغر اض البحث العلمي فقط و سوف تبقى هوية المشار آين فيه } \\
& \text { مجهولة تماما. } \\
& \text { الموقف الأول: أنت طالب في الجامعة و بحاجة إلى آتاب (مرجع) من المكتبة لإتمام بحث مطلوب منك تسليمه في وقت محدد.المكتبة مغلقة, هناك } \\
& \text { شخص واحد تعرف أن لديه المرجع و هو احد مدرسيك, شاهدت هذا المدرس في طريقه إلى مكتبه, ماذا ستقول له؟ } \\
& \text { الموقف الثاني: أنت بحاجة إلى ساعة من الوقت لإتمام بعض المهام خارج المدينة, ذهبت إلى المسؤول عنك في العمل ( مع العلم أنك على علاقة }
\end{aligned}
$$

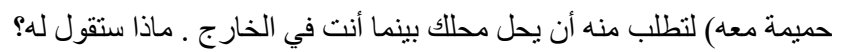

$$
\begin{aligned}
& \text { الموقف الثالث: أنت موظف في شر آة منذ فترة من الزمن , إحدى واجباتك في العمل هي الإجابة على المكالمات , ذهبت إلى مكتب احد المندربين } \\
& \text { الجدد في الثر آة لتطلب منه أن يجيب على الهاتف بينما أنت في الخارج لبضع دقائق لإحضار بعض الأشياء ـ ماذا ستقول له؟ } \\
& \text { الموقف الرابع: أنت مع صديقك في السيارة ,و أنت السائق, آلآما يقصد شارع عبدا لله خياطو أضعتما الطريق, و فجأة رأيتما احد المارة في نهاية } \\
& \text { الثارع, طلبت من صديقلك أن يسال ذلك الثخص عن الاتجاه الصحيح. ماذا ستقول لصديقك؟ الصع } \\
& \text { الموقف الخامس: أنت بحاجة لنقل بعض الأغر اض من بيتك و لم ترتب لذلك بإحضار شخص يساعدك لان آل أصدقائك في إجازة و لم تطلب } \\
& \text { وسيلة نقل لأنك لا تملك النقود رشاهدت جارك (الذي لا تعرفه جيدا) و الذي يملك سيارة , تريد أن تطلب منه مساعدتك في نقل الأغر اض ـ ماذا } \\
& \text { ستقول له } \\
& \text { الموقف السادس: تعطلت سيارتك و أنت بحاجة ماسة لإحضار شخص من المطار, و لا يوجد وسيلة نقل إلى المطار إلا السيار ات الخاصة, ذهبت } \\
& \text { إلى مكتب رئيسك في العمل, الذي أنت على علاقة حميمة معله, لتطلب منه أن يعيرك سيارنه. ماذا ستقول له ؟ } \\
& \text { الموقف السابع: تم تعينك آمسؤول عن مشروع مهم في العمل ـ أحد زملاءك في المشروع قد حجز نذآرة طائرة للاستمتاع بعطلته. و أدرآت أنلك }
\end{aligned}
$$




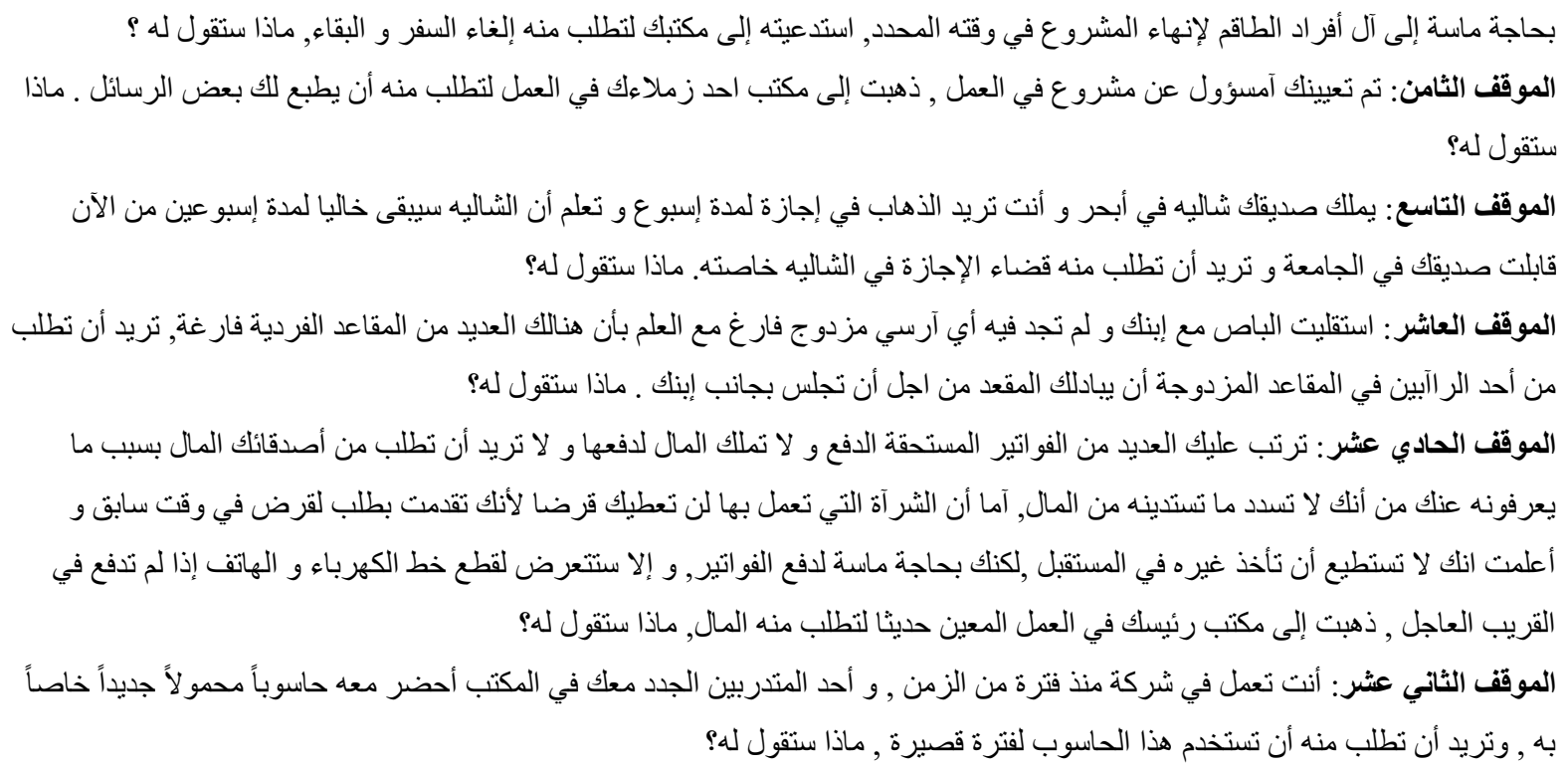

\section{Appendix II: Questionnaire--English Version}

Instructions:

You will be asked to read brief situations; you will have to act as you would in an actual situation.

Do not think too much and try to be as spontaneous as possible. This questionnaire will be used for research purposes only. Thank you for your cooperation.

Name: (optional): Age: Major:

SEX: $\quad \mathrm{M}(\quad) \quad \mathrm{F}(\quad)$

Situation 1: You are a university student. You need to get the book from the library to finish your assignment on time. The library is closed and there is only one person you know who has the book you need, one of your lecturers. On the way to his/her office you meet him/her in the hallway. What do you say?

Situation 2: You need to run few errands down town. You think that will take you an hour. You go to your manager/ess's office at work with whom you get on well and ask him/her to cover for you. What do you say?

Situation3: You have been an employee of a company for some time now. One of your duties is to answer the telephone. You go to the desk of new trainee and ask him/her to answer the telephone while you pop out for a few minutes to get some things. What do you say to him/her?

Situation4: You are in your car with a friend. You are driving. You both need to go to X Street. Your friend was given a map with directions which s/he gave to you just before leaving the house. You are now lost. You suddenly see a pedestrian at the end of the road. You ask your friend to ask the pedestrian for directions. What do you say to your friend?

Situation5: You ask neighbor you do not know very well to help you move some things out of your apartment with his/her car since you have not got a car and you have not got anyone else to ask since everyone you know appears to be on a holiday and you have no money either to hire someone who can help or to arrange transport. You see your neighbor on the street. What do you say to him/her?

Situation6: Your car has just broken down and you need to collect someone from the airport urgently and there is no other means of getting there other than by car. You go to your manager/ess's office at work, with whom you get on well, and ask him/her for his/her car. What do you say to him/her?

Situation7: You have been put in charge of a very important project at work. Your colleague has already booked a ticket to go on a holiday. You realize you will be needing all members of the staff to finish the project on time and thus you ask him/her to stay. You ask him/her to come to your office to break the news. What do you say to him/her?

Situation8: You have been put in charge of new project at work. You go to the desk of your colleague of yours to ask him/her to type a few letters for you. What do you say to him/her? 
Situation9: A friend of yours has a house in countryside. You want to go on a holiday somewhere relaxing for a week and you know nobody is going to be in the house for at least two weeks. You meet your friend in a pub and ask him/her to stay in his/her country house for a week. What do you say to him/her?

Situation10: You are on a bus with a child. There are plenty of seats on the bus but there are not any for two people together. You ask a passenger who is sitting on his/her own on a two-seater to change seats with you so that you can sit next to the child. What do you say to him/her?

Situation11: You have received a lot of house bills which are due for payment. You have not got any money. You cannot ask your friends for money since you have got a reputation of never paying back. The company where you work will not give you a cash advance since the last time you asked for one they said that would be the last time. You desperately need to pay these bills otherwise you will not have any electricity, gas or telephone. You go to the office of the recently appointed manager/ess and ask him/her for the money. What do you say to him/her?

Situation12: You have been working for a company for some time now. One of the new trainees has brought his/her new brand laptop to work. You ask him/her to use it for a while. What do you say to him/her? 